\title{
REMOTE WORK DURING THE COVID-19 PANDEMIC: - PROBLEMS AND SOLUTIONS ON THE EXAMPLE OF VIDZEME REGION IN LATVIA
}

\author{
Lilita Langovska1 ${ }^{1}$, Mg. candidate; Sarmite Rozentale², Dr.oec., Professor \\ 1, 2 Vidzeme University of Applied Sciences
}

\begin{abstract}
The aim of the research was to study the experience of companies in the transition to remote work during the COVID-19 pandemic. The development of information and communication technologies in the $21^{\text {st }}$ century has transformed everyday work and life, and it was expected that, over time, teleworking would become a common practice in most companies. However, it was slower than initially expected due to various social and organizational factors. The COVID-19 pandemic accelerated the shift to forced remote work, creating problems and challenges for both employers and employees. This proves that new approaches and solutions are not only possible, but also useful and necessary. In order to find out what challenges employers have faced in the transition to remote work and what experience they have gained in order to solve them, two focus group discussions were organized with employers of Vidzeme region from different sectors. In order to compare the experience of employers and employees, a survey of 495 remote-working respondents was conducted between September and October 2020. The research data were collected in the framework of the National Research Programme project "Life with COVID-19", during the first wave of the pandemic. The study reveals that the main challenges were to adapt business processes to the constraints of the emergency and the work organization of remote work, which requires new knowledge and skills such as how to sell, communicate, motivate, teach remotely and ICT skills. Teleworking during the COVID-19 pandemic posed challenges such as occupational safety risks, health risks, separating work from leisure time and acquiring new knowledge and skills in a short time.
\end{abstract}

Key words: business processes, management, remote work, Vidzeme region, COVID-19 pandemic.

JEL code: $M 1, M 10, M 12, M 21$

\section{Introduction}

With the COVID-19 pandemic, the work and its management in companies changed. The social distancing measures introduced in all countries during the COVID-19 pandemic brought about great changes in the employment sphere forcing both employers and employees to work from home for health reasons. Most companies encountered remote work for the first time. The COVID-19 emergency situation and the restrictions imposed within it not only in Latvia, but also in the world significantly affected business in certain sectors and also had an impact on employment in these sectors. Therefore, it was important to adapt business processes to the restrictions of the emergency and the work organization of remote work, which required new knowledge and skills. This study showed how successfully remote work was integrated into Vidzeme region companies during the first wave of the COVID-19 pandemic. Forced transition to remote work has created problems and challenges for both employers and employees, and this confirms the need for a new approach and new solutions in company management and work organization. The aim of the study is to investigate and analyse what factors influenced remote work during the COVID-19 pandemic and how they were addressed by the employers in Vidzeme region, providing an opportunity to integrate the findings of this study into business management when switching to remote work.

Based on the aim of the study, two research questions were defined.

1) What factors have influenced the management and organization of remote work?

2) What were the positive and negative experiences of employers and employees in Vidzeme region in the transition to remote work during the COVID-19 pandemic?

The following steps were taken in order to find out what challenges employers have faced in the transition to remote work and what experience they have gained.

1 Business Environment Administration Master's Study Programme, Cesu str.4, LV4201, Latvia

2 Institute of Social, Economic and Humanities Research of Vidzeme University of Applied Sciences, Cesu str.4, LV4201, Latvia 
First, the authors analysed policy documents and previous research on the management and organization of remote work. As a result, factors influencing remote work were identified. The analysis of the Eurofound research was performed in relation to the concept of remote work and the regulation of remote work in various EU Member States, including Latvia, for example, the European Foundation for the Improvement of Living and Working Conditions publication of 28 July 2020 "Regulations to address worklife balance in digital flexible working arrangements, New forms of employment series" (Llave et al., Eurofound, 2020), as well as the study published by Eurofound on 6 November 2020 on living and working under the influence of COVID-19 "Living, working and COVID-19". In addition, the amendments to the Labour Protection Law of the Republic of Latvia were analysed.

Second, two semi-structured focus group interviews were organized with 11 employers in Vidzeme region. The interviews were conducted in person in September 2020, thus the results of the focus groups describe the companies' experience acquired during the emergency situation declared in March. A targeted sample was used for the interviews: employers of companies of different sizes (based on the number of employees) were selected, representing different sectors (see Table 2). The interviews allowed obtaining data on what was happening in the companies in Vidzeme region and understanding the situation development trends.

Third, by using content analysis, the challenges and benefits of remote work in the context of COVID-19 were assessed observing anonymity in data processing. The data of this study were obtained in the project of the National Research Programme of Latvia "Life with COVID-19: Evaluation of the overcoming coronavirus crisis in Latvia and recommendations for social resilience in the future".

Finally, a survey of employees was conducted to compare the identified problems of employers and employees while working remotely during the COVID-19 pandemic. Econometric research methods were used - mathematical statistics, factor analysis, data input quality control, data cleaning and weighing. The sample structure of the study was based on the latest data of the Latvian Central Statistical Bureau. The target group of the study was the remotely working population of Latvia (180 000 employees). A statistical approach was used to assess the size of the sample and the confidence level of the result. According to the statistical calculation, the recommended selected sample was 384 respondents, the confidence level $95 \%$ and the margin of error $5 \%$. Using the number of respondents (495) decreased the estimation of error to $4.4 \%$. The obtained survey data were analysed with the data processing programme IMB SPSS version 26 and visualized using MS Excel. First, the respondents who worked remotely during the COVID-19 pandemic were selected - there were 495 such respondents, of which 82 were employed in Vidzeme region.

In order to create the structure of the interview and to develop the survey, previous research on remote work was analysed. Such research was conducted before the COVID-19 pandemic, for example, several scientists have identified occupations that can be performed remotely and sectors where remote working is a successful alternative in work organization (Overbey, 2013). The studies have concluded that organizational factors are crucial for performing remote work (Baker, Avery and Crawford, 2007; Grant et al. 2019). These studies show that employers support employees' requirements when working from home, providing employees with everything they need for remote work to succeed, such as compensating for equipment costs, training in the use of technology, and organizational communication. This study highlights the need for a range of sustainable human resource management strategies and effective employee training and development programmes (Dima et al., 2019). Baruch and Nicholson (1997) define four factors influencing remote work: individual factors, work factors, organizational factors, and family / home factors. During the COVID-19 pandemic, studies covering the impact of the pandemic have been published, for example, Belzunegui-Eraso and Erro-Garcés (2020) analyse remote work as a safety tool in the COVID-19 
pandemic conditions in their research "Teleworking in the Context of the COVID-19 Crisis", which supplements Baruch and Nicholson (1997) approach to remote work with environmental, security and legal factors (Belzunegui-Eraso, Erro-Garcés, 2020; Baruch, Nicholson, 1997). In addition, the study "Workaholism and Technostress During the COVID-19 Emergency: The Crucial Role of the Leaders on Remote Working" points to increasing levels of stress in the transition to remote work (Spagnoli et al., 2020). The data from several studies suggest that attention should be paid that employers provide more support to their employees - both in organizing remote work (for example, in terms of setting up an ergonomic workplace, reimbursing expenses), in providing psycho-emotional support and in organizing training.

\section{Research results and discussion}

\section{Factors influencing remote work}

The analysis of the previous studies and legislation identified the most significant factors influencing the transition to remote work during the COVID-19 pandemic (Table 1). 
Factors influencing the transition to remote work during the COVID-19 pandemic

\begin{tabular}{|c|c|c|}
\hline \multirow{2}{*}{ No } & \multirow{2}{*}{ Factors } & Explanation \\
\hline & & External environment factors \\
\hline 1. & $\begin{array}{l}\text { Information provided by } \\
\text { the state in connection } \\
\text { with the COVID-19 } \\
\text { pandemic }\end{array}$ & $\begin{array}{l}\text { The most important sources of information from state institutions were the Centre } \\
\text { for Disease Prevention and Control, the Ministry of Health, the Ministry of Welfare, } \\
\text { the State Labour Inspectorate, the Ministry of Economics, the Consumer Rights } \\
\text { Protection Centre, the websites of these institutions and the website maintained } \\
\text { by several institutions www.stradavesels.Iv. }\end{array}$ \\
\hline 2. & $\begin{array}{l}\text { Legislation of the Republic } \\
\text { of Latvia }\end{array}$ & $\begin{array}{l}\text { Changes in legislation during the first wave of the pandemic: In Latvia, the } \\
\text { amendments to the Labour Protection Law entered into force as of } 1 \text { July } 2020 \text {. }\end{array}$ \\
\hline 3. & $\begin{array}{l}\text { Electricity and Internet } \\
\text { provision }\end{array}$ & $\begin{array}{l}\text { During COVID-19, when many worked remotely from home, household electricity } \\
\text { consumption patterns also changed and the number of Internet connections } \\
\text { increased. }\end{array}$ \\
\hline \multicolumn{3}{|r|}{ Internal environment factors } \\
\hline 4. & Employment & $\begin{array}{l}\text { Reduction/ increase of workload, forced leave, downtime, dismissal/ recruitment } \\
\text { of employees. }\end{array}$ \\
\hline 5. & Changes in revenue & $\begin{array}{l}\text { The COVID-19 pandemic can cause a decrease or increase in revenue, depending } \\
\text { on the industry of the company. }\end{array}$ \\
\hline 6. & $\begin{array}{l}\text { Expenditure on COVID-19 } \\
\text { protective equipment }\end{array}$ & Budget spending may increase. \\
\hline 7. & Changes in workload & $\begin{array}{l}\text { The volume of work decreased or increased depending on the industry of the } \\
\text { company. }\end{array}$ \\
\hline 8. & $\begin{array}{l}\text { Changes in customer trust } \\
\text { levels }\end{array}$ & $\begin{array}{l}\text { Retaining and attracting customers became a challenge. Demand for online stores } \\
\text { increased. }\end{array}$ \\
\hline 9. & Efficiency of remote work & $\begin{array}{l}\text { Before the COVID- } 19 \text { pandemic, entrepreneurs had no experience working with } \\
\text { restrictions and remotely. Management, control, accounting of working hours. }\end{array}$ \\
\hline 10. & $\begin{array}{l}\text { Internal and external } \\
\text { communication }\end{array}$ & $\begin{array}{l}\text { During the COVID- } 19 \text { pandemic, communication is an important factor influencing } \\
\text { the relationships with partners and employees, as the way of concluding } \\
\text { transactions, signing contracts, establishing contacts, as well as communicating } \\
\text { with employees in the emergency changed. }\end{array}$ \\
\hline 11. & ICT provision & $\begin{array}{l}\text { The provision of new technologies and software can be a challenge for many } \\
\text { companies if ICT equipment is not suitable for remote work, which can lead to } \\
\text { additional costs. }\end{array}$ \\
\hline 12. & $\begin{array}{l}\text { Remote training and } \\
\text { professional development } \\
\text { of employees }\end{array}$ & $\begin{array}{l}\text { The transition to remote working changed the content and organization of } \\
\text { employee training and professional development, for example, webinars, } \\
\text { conferences, online courses, stress management, time management. }\end{array}$ \\
\hline 13. & Safe work environment & $\begin{array}{l}\text { When working remotely, it is necessary to ensure an ergonomic work environment, } \\
\text { observe work safety, as well as identify employees who are at risk. }\end{array}$ \\
\hline 14. & Motivation of employees & $\begin{array}{l}\text { When working remotely, motivational tools change, for example, the bonus } \\
\text { system, ICT provision, job accounting and control, the level of trust. }\end{array}$ \\
\hline
\end{tabular}

Source: Authors' creation based on the literature analysis (Belzunegui-Eraso, Erro-Garcés, 2020; Baruch, Nicholson, 1997, Livina at al.,2016).

\section{Participants of the interviews and survey}

In order to find out how the previously mentioned factors have affected companies in Vidzeme region, two structured employer focus group interviews were conducted. The characteristics of the interviewees are shown in Table 2. 
Descriptive analysis of the participants of the interviews

\begin{tabular}{|c|c|c|}
\hline $\begin{array}{l}\text { Respondent } \\
\text { ID }\end{array}$ & Sector represented (according to NACE 2 classification) & 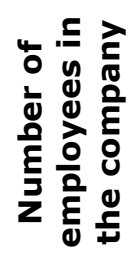 \\
\hline A & $\begin{array}{l}\mathrm{N} \text { : Administrative and support service activities, L: Real estate } \\
\text { activities }\end{array}$ & 3 \\
\hline B & $\begin{array}{l}\text { G: Wholesale and retail trade; repair of motor vehicles and } \\
\text { motorcycles }\end{array}$ & 3 \\
\hline C & M: Professional, scientific and technical activities & 4 \\
\hline D & P: Education & 3 \\
\hline $\mathbf{E}$ & J: Information and communication & 41 \\
\hline $\mathbf{F}$ & M: Professional, scientific and technical activities & N/A \\
\hline G & $\mathrm{H}$ : Transportation and storage & 251 \\
\hline H & A: Agriculture, forestry and fishing & 61 \\
\hline $\mathbf{I}$ & $\begin{array}{l}\text { G: Wholesale and retail trade; repair of motor vehicles and } \\
\text { motorcycles } \\
\text { F: Construction }\end{array}$ & 28 \\
\hline J & P: Education & 120 \\
\hline $\mathbf{K}$ & L: Real estate activities & 46 \\
\hline $\mathbf{L}$ & $\mathrm{J}$ : Information and communication & 272 \\
\hline M & $\begin{array}{l}\text { E: Water supply, sewerage, waste management and remediation } \\
\text { activities }\end{array}$ & 86 \\
\hline $\mathbf{N}$ & $\mathrm{J}$ : Information and communication & 70 \\
\hline $\mathbf{0}$ & K: Financial and insurance activities & 1800 \\
\hline
\end{tabular}

Source: Focus group discussions with the employers in Vidzeme region from 22 September 2020 and 29 September 2020

The e-survey was disseminated via a link on publicly available sites, social networks, as well as through direct e-mails from 28 September 2020 to 27 October 2020. Anyone with access to the Internet could complete the e-survey, but it had a filter question that allowed selecting employees who had access to the full version of the survey (for example, people who had not worked during the last year or were housewives at the time of completing the questionnaire were not asked all the questions). All the questions were answered by 1006 respondents, of which 495 worked remotely. The characteristics of the respondents were: industry of the company (according to NACE 2 classification), type of residence (Table 3). The survey data were collected and managed using the REDCap (Research Electronic Data Capture) electronic data collection and compilation tool. REDCap is a secure, web-based software platform designed to support data collection for research. 


\section{Descriptive analysis of the respondents}

\begin{tabular}{|c|c|c|}
\hline Sector represented (according to NACE 2 classification) & Vidzeme & $\begin{array}{c}\text { Other regions } \\
\text { of Latvia }\end{array}$ \\
\hline A: Agriculture, forestry and fishing & $3.9 \%$ & $2.3 \%$ \\
\hline C: Manufacturing & $5.2 \%$ & $3.9 \%$ \\
\hline D: Electricity, gas, steam and air conditioning supply & $2.6 \%$ & $2.6 \%$ \\
\hline E: Water supply, sewerage, waste management and remediation activities & $2.6 \%$ & $1.0 \%$ \\
\hline F: Construction & $6.5 \%$ & $3.3 \%$ \\
\hline G: Wholesale and retail trade; repair of motor vehicles and motorcycles & $2.6 \%$ & $3.1 \%$ \\
\hline H: Transportation and storage & $1.3 \%$ & $4.6 \%$ \\
\hline J: Information and communication & $7.8 \%$ & $5.4 \%$ \\
\hline K: Financial and insurance activities & $0.0 \%$ & $3.6 \%$ \\
\hline L: Real estate activities & $0.0 \%$ & $0.3 \%$ \\
\hline M: Professional, scientific and technical activities & $6.5 \%$ & $6.4 \%$ \\
\hline $\mathbf{N}$ : Administrative and support service activities & $2.6 \%$ & $2.1 \%$ \\
\hline O: Public administration and defence, compulsory social security & $13.0 \%$ & $20.8 \%$ \\
\hline P: Education & $33.8 \%$ & $29.6 \%$ \\
\hline Q: Activities of extraterritorial organisations and bodies & $1.3 \%$ & $4.4 \%$ \\
\hline R: Arts, entertainment and recreation & $3.9 \%$ & $1.0 \%$ \\
\hline S: Other service activities & $6.5 \%$ & $5.7 \%$ \\
\hline
\end{tabular}

Source: Employee survey from 28 September 2020 to 27 October 2020, n-495

\section{Results of the employer focus group discussions}

Analysing the results of the focus group interviews, one of the challenges of the external environment was the information and communication provided by the state to the public about the restrictions and precautionary measures of the COVID-19 pandemic. The most important sources of information from state institutions were the Centre for Disease Prevention and Control, the Ministry of Health, the Ministry of Welfare, the State Labour Inspectorate, the Ministry of Economics, the Consumer Rights Protection Centre, as well as the website www.stradavesels.Iv maintained by several institutions. However, the analysis of the interviews shows that employers used Internet portals (for example, www.delfi.lv, www.tvnet.lv), social network accounts, as well as direct telephone consultations more. The participants of the interviews acknowledged that the information provided by the state was general and voluminous, which sometimes led to aggression, confusion and panic, as the information was tendentiously interpreted in the media and on social networks. The employers of large companies also admitted during the interview that there was enough information, but it was relatively contradictory. The employers indicated that the communication of the public administration institutions in the e-environment should be improved.

Another external environment factor was the changes in legislation in the country related to the COVID-19 pandemic when companies had to comply with new requirements for remote working. Analysing the situation in the field of regulatory enactments, it can be concluded that, even though remote work was performed in Latvia before the emergency situation caused by the COVID-19 pandemic, the legislation regulating the field of remote work is new and was not in force before the first wave of COVID-19 in 2020. The analysis of the employer interviews shows that remote working at home does not meet the occupational 
safety requirements. The survey of employees shows that $81.7 \%$ of the participants from Vidzeme region did not have a written agreement on performing remote work with the employer, but in Latvia as a whole $-76.0 \%$

The analysis of the focus group interviews of employers shows that a significant aid provided by the state was the introduction of downtime benefits. Examining the regional distribution of the cost of benefits, it can be seen that half of all recipients of downtime benefits are declared in Riga, but $20 \%$ in Pieriga, while in other regions the share is lower - $9 \%$ in Kurzeme, $9 \%$ in Zemgale, $6 \%$ in Vidzeme and $6 \%$ in Latgale (State Revenue Service of the Republic of Latvia, 07.05.2020). Analysing the interviews, it was seen that, even though employers faced difficulties, sometimes terminating their activities, the downtime benefits made it possible to keep existing jobs and employees.

An important external environment factor that affects the performance of remote work is the uninterrupted supply of electricity and the provision of the Internet. The analysis of the focus group interviews revealed that the power supply infrastructure of buildings did not correspond to the power consumption during the COVID-19 pandemic and was not able to ensure an uninterrupted supply of electricity. As people were forced to isolate themselves and work remotely from home using information communication technologies, electricity disruptions occurred that affected the electricity supply of many apartment buildings.

During the COVID-19 pandemic, many good and talented specialists became available in the labour market, which, according to the analysis of the interviews, was successfully used by employers in Vidzeme region. Before the pandemic, good specialists were concentrated in the capital and did not want to work in regional cities (Livina, Rozentale, 2020), but, thanks to the COVID-19 pandemic, people moved from the capital to regional cities.

The analysis of the focus group interviews revealed that the companies faced additional costs related to the provision of protective equipment on the company's premises, disinfectants, face masks and face shields were purchased, the cleaning of the premises was intensified, and the companies faced a shortage of this equipment, but the costs of the protective equipment increased with each order, which created an additional burden for the budgets of small businesses. As well as that, the employers also emphasized that during the emergency they had saved both financial resources (for example, not spending money on business trips, not paying sick leaves because the absence of employees due to illness decreased), and time.

The results of the research analysis show that during the COVID-19 pandemic work duties and workload increased. Analysing the focus group interviews of the employers, it was revealed that the most important task in entrepreneurship faced by the entrepreneurs in many sectors during the COVID-19 pandemic was retaining and maintaining market positions, as well as e-commerce development. The workload of the representatives of the information technology company increased many times, because there was a great demand for online stores, but many companies did not have an online store.

The analysis of the interviews shows that, when working remotely with ICT tools, the workload remains the same, however, the work time spent on servicing ICT tools, various software, and communication time with colleagues, the employer, and customers on communication platforms increases, and, as a result, work efficiency decreases. Communication in business plays a very important role in building cooperation. Analysing the results of the research, it can be seen that making new contacts became a significant challenge during the COVID-19 pandemic.

Internal communication processes were equally important during the COVID-19 pandemic, creating a clear understanding of what people need to hear and see in order to switch to remote working more 
successfully, making it a successful management process. The focus group discussions showed that employers chose such online way of communicating with employees that was more relevant to their industry, such as WhatsApp, using the ZOOM programme. The rapid transition to remote working affected companies' internal communication. The employee survey data show that $81.7 \%$ of Vidzeme region respondents were provided with the necessary software for remote work (ZOOM, Webex and other).

The interview data show that the challenge for the transition to remote work was the provision of ICT. It turned out that small businesses are not ready to switch to remote work due to outdated technologies, which require additional investments, such as the purchase of laptops and additional equipment. It was easier for the large employers to provide the possibility for employees to work remotely. The analysis of the survey data of employees shows that $17 \%$ of the respondents in Vidzeme region and $29 \%$ of other respondents in Latvia needed a computer and other IT equipment when performing remote work, but it was not provided or was provided only in some cases (Fig. 1).

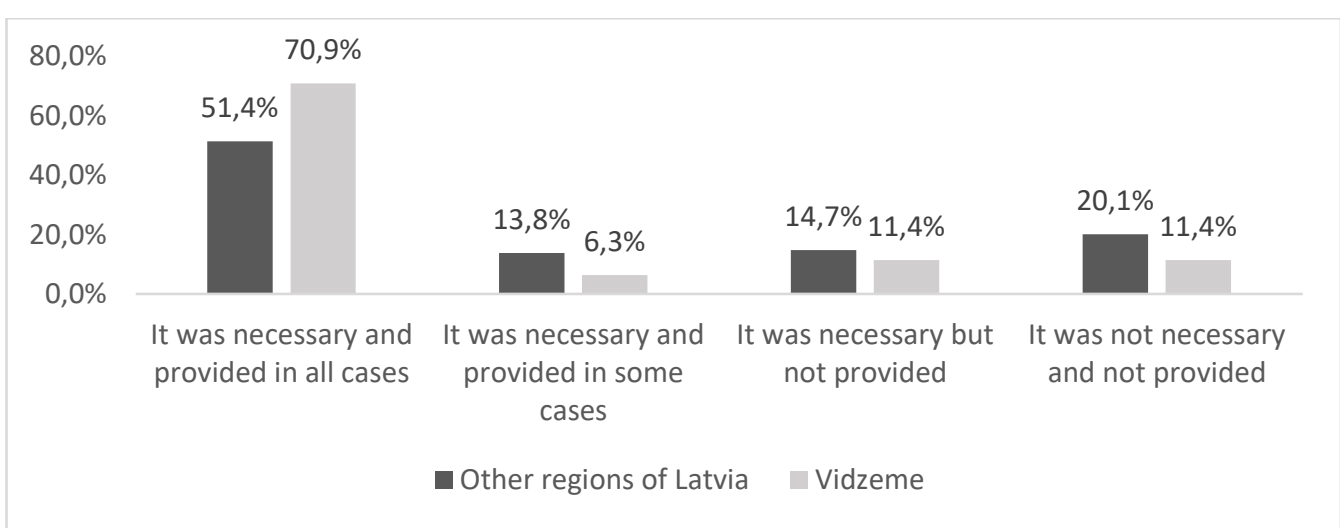

Source: author's calculations based on the employee survey from 28 September 2020 to 27 October 2020 , $n-495$

\section{Fig. 1. Provision of computers and other IT equipment for remote employees during the COVID-19 pandemic}

The transition to remote working required employers and employees to quickly learn and improve their skills for working outside the office. The training offers during the COVID-19 pandemic were very diverse. There are several advantages for companies when using online training. The study shows that companies have also used global and local training platforms for employee training (a quote from a large company employer of Vidzeme region: "We continued as usual; we provided more information about the recently introduced possibility to use the global training platform Linked Learning with more than 8000 training courses. "). The analysis of the survey data of employees shows that $20 \%$ of teleworkers in Vidzeme region have not improved their skills either on their own initiative or at the initiative of employers, but in other regions of Latvia - $14 \%$ of teleworkers (Fig. 2). 


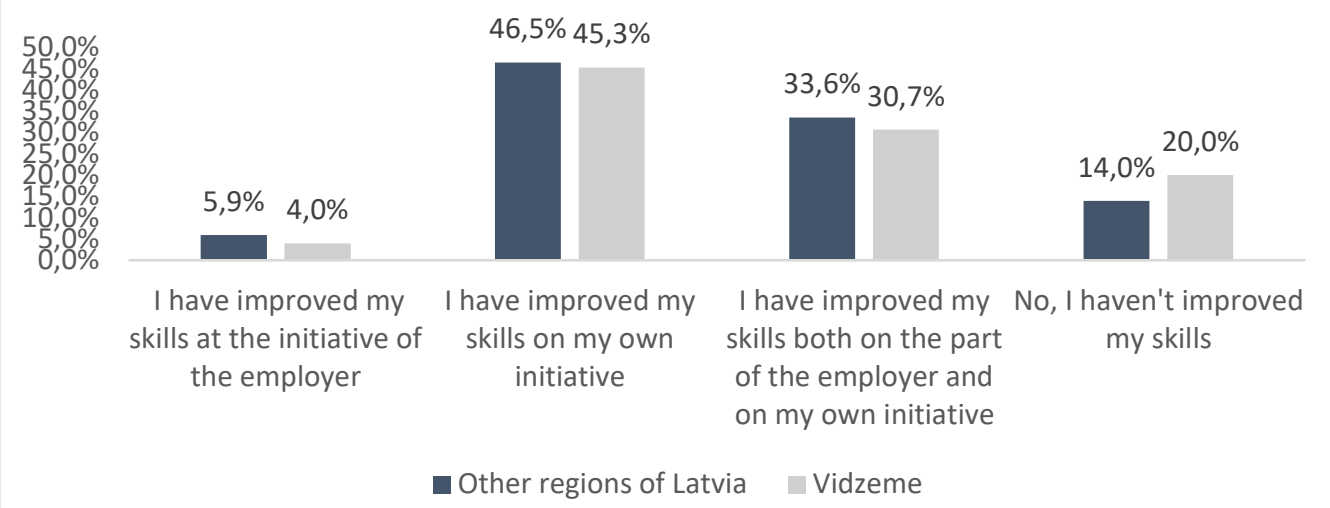

Source: author's calculations based on the employee survey from 28 September 2020 to 27 October 2020, $n-495$

Fig. 2. Improving the skills of teleworkers during the COVID-19 pandemic

The focus group discussions were organized in the autumn of 2020 - several months after the end of the emergency situation, when the requirements of the regulatory enactments regarding the assessment of the work environment risk for remote workplaces were already in force. The entrepreneurs acknowledged that the work environment risk assessment for remote workplaces had not been performed and that risk groups had not been identified. When working remotely, employees face many risks, for example, increased psychological load, employees experience stress that they cannot combine private life with work responsibilities that have to be performed remotely. The employers admitted that the employees' work environment at home had not been inspected, and the provision of technologies and the Internet connection could be mentioned as the maximum supportive measure on the part of the employer.

The analysis of the employee survey data reflects the benefits of teleworking during the COVID-19 pandemic. Most of all the respondents from Vidzeme region have appreciated the possibility to save time on the way to and from work (64.6\%), to plan a daily routine, balancing work and private life (63.4\%) and the reduction of transport expenses (52.4\%), as well as savings in the household budget (52.4\%). There is a similar tendency in the answers of respondents from other regions of Latvia. The biggest differences between Vidzeme region and other regions of Latvia are observed in the decrease of stress level ( $23.2 \%$ Vidzeme, $14.5 \%$ other regions of Latvia) and the possibility to live in the countryside (12.2 \% Vidzeme, $18.2 \%$ other regions of Latvia, which also includes the capital Riga) (Fig. 3). 


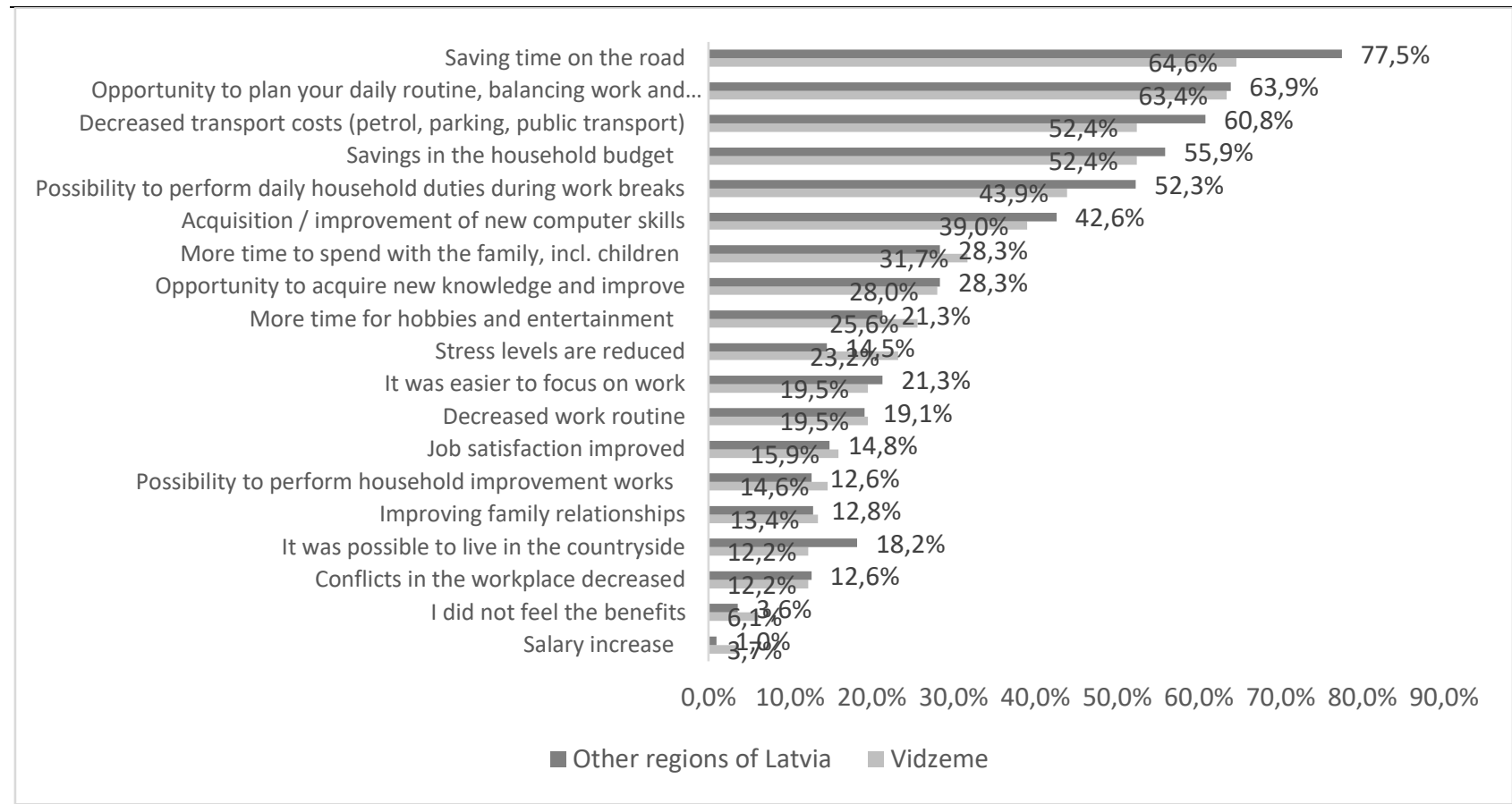

Source: author's calculations based on the employee survey from 28 September 2020 to 27 October 2020 , $n-495$

Fig. 3. Benefits of telework for Vidzeme region teleworkers during the COVID-19 pandemic

The biggest challenges of telework in both groups of the respondents - Vidzeme and other regions of Latvia - have been the lack of communication and socialization, but this also reflects the biggest difference between the two groups of respondents. The respondents of other regions of Latvia, including Riga, lacked communication by $10.6 \%$ more than the respondents of Vidzeme region. This could possibly be explained by differences in leisure habits in cities and rural areas, but such a statement requires more in-depth research. The respondents from other Latvian regions also more often felt lonely in comparison with the respondents from Vidzeme region.

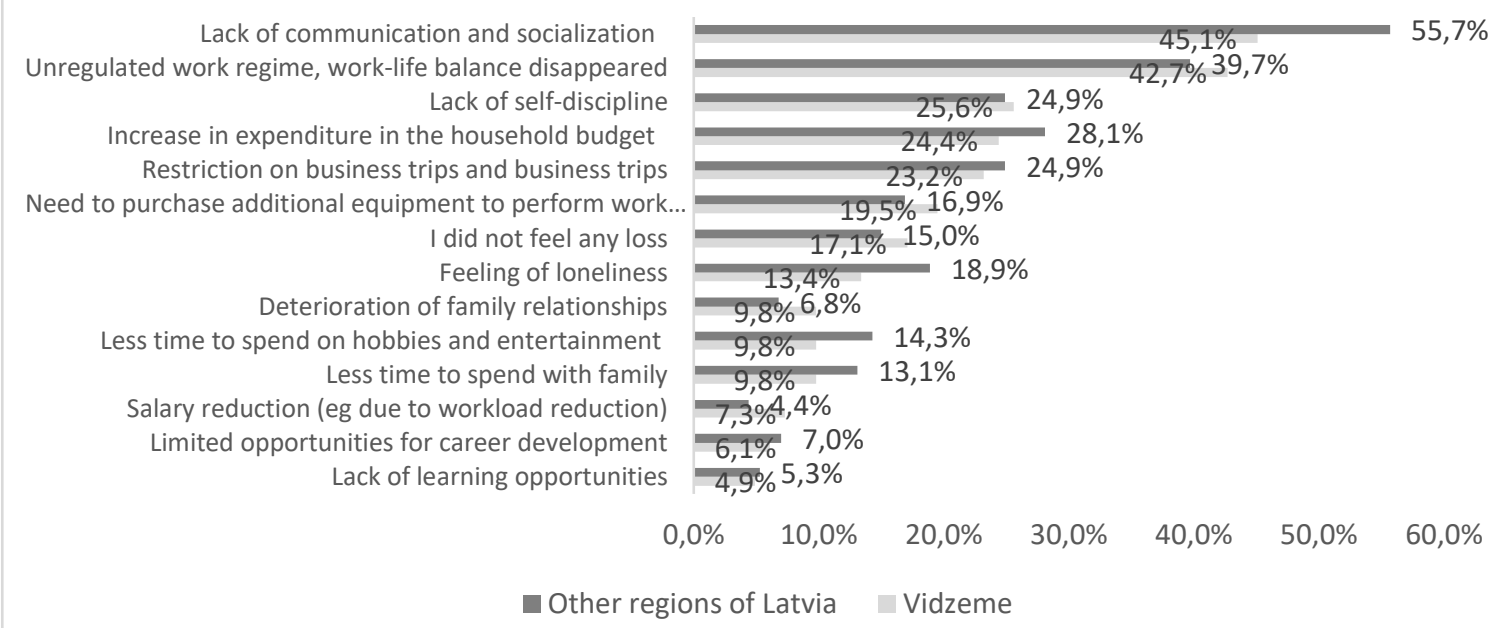

Source: author's calculations based on the employee survey from 28 September 2020 to 27 October 2020, $n-495$

Fig. 4. Challenges of telework during the COVID-19 pandemic 
There have also been several limitations to our study. One of the limitations of the web-based survey method is the fact that some groups of employees may be excluded from the sample by default (such as the elderly, people living in remote areas, and people with low education level and digital skills). The questionnaire was only available in Latvian, which probably resulted in fewer responses from the Russianspeaking population. In order to obtain data representing the demographic profile of the working age population in Latvia, the sample was weighted by sex and age.

\section{Conclusions, proposals, recommendations}

1) Extensive information was provided by public authorities during the COVID-19 pandemic, but small businesses were sometimes unable to navigate the news flow and mostly used social networks and the media as a source of information. The solution could be to involve municipalities, planning regions, business associations so that small businesses receive information in a timely manner. It would be necessary to create a single website devoted to the emergency situation where the information on the emergency situation would be gathered by all institutions involved in crisis management.

2) It would be necessary to promote employers' awareness of the need to legally formalize remote working by agreeing with remote workers, providing a term for remote working in the employment contract or its amendments and defining the employer's and employee's rights and responsibilities for occupational safety and health, data protection, working time and its accounting, risk assessment, compensation for expenses related to remote work.

3) The most economical home Internet connection speed chosen sometimes did not correspond to performing efficient remote work. These circumstances should be taken into account when deciding on remote work also after the COVID-19 pandemic.

4) Companies faced additional costs associated with the provision of protective equipment, but the cost of these materials increased with each order, which placed an additional burden on the budget for small businesses. The possibilities for the state to influence the availability and price of protective equipment during an emergency situation should be considered (for example, through centralized procurement at the state or municipal level, setting price increase ceilings).

5) Communication became a major challenge during the COVID-19 pandemic, affecting relations with partners and employees, as the way in which transactions were made, contracts signed, contacts established and the way how to communicate with employees in an emergency changed. Municipalities and business associations should organize and promote online experience exchange events for business leaders on business success stories in the context of the crisis, strengthening employers' skills in managing employees and organizing work in the case of remote work.

\section{Acknowledgements}

The data of this study were obtained in the project of the National Research Programme of Latvia "Life with COVID-19: Evaluation of overcoming the coronavirus crisis in Latvia and recommendations for societal resilience in the future" (Nr. VPP-COVID-2020/1-0013). The analysis of data and theoretical sources were performed in the framework of the master's thesis developed by the author of the article Lilita Langovska in Vidzeme University of Applied Sciences Business Environment Administration study programme. The development of this study was funded by the Institute of Social, Economic and Humanities Research of Vidzeme University of Applied Sciences. 


\section{Bibliography}

1. Baker, E., Avery, G. C., and Crawford, J. (2007). Satisfaction and Perceived Productivity When Professionals Work from Home.[pdf] Research \& Practice in Human Resource Management, 15 (1): 37-62.

Retrieved:https://opus.lib.uts.edu.au/bitstream/10453/6434/1/2007000202.pdf Access: 13.03.2021.

2. Baruch, Y., Nicholson, N. (1997). Home, Sweet Work: Requirements for Effective Home Working. J. Gen. Manag.1997, 23, 15-30.

3. Belzunegui-Eraso, A., \& Erro-Garcés, A. (2020). Teleworking in the Context of the COVID-19 Crisis, Sustainability, MDPI, Open Access Journal, vol. 12(9), pages 1-18, May. Retrieved: https://www.mdpi.com/2071-1050/12/9/3662/htm Access: 14.03.2021.

4. Dima, A.M., Tuclea, C.-E.,Vrânceanu, D.-M., and Tigu, G. (2019) Sustainable Social and Individual Implications of Telework: A New Insight into the Romanian Labor Market. Sustainability 2019,11, 3506. Retrieved: https://www.mdpi.com/2071-1050/11/13/3506/htm Access: 14.03.2021.

5. Ekonomikas ministrija (27.08.2020). Latvijas Makroekonomiskais apskats. Retrieved: https://www.em.gov.Iv/lv/latvijas-makroekonomiskais-apskats Access: 14.03.2021.

6. Eurofound (2020). Living, working and COVID-19, COVID-19 series, Publications Office of the European Union, Luxembourg. Retrieved: https://www.eurofound.europa.eu/publications/report/2020/living-working-andCOVID-19 Access: 14.03.2021.

7. Eurofound (2020). Telework and ICT-based mobile work: Flexible working in the digital age, New forms of employment series, Publications Office of the European Union, Luxembourg. Retrieved: https://www.eurofound.europa.eu/publications/report/2020/telework-and-ict-based-mobile-work-flexibleworking-in-the-digital-age\#tab-01 Access: 14.03.2021.

8. Grant, C. A., Wallace, L. M., Spurgeon, P. C., Tramontano, C. and Charalampous, M. (2019). Construction and Initial Validation of the e-Work Life Scale to Measure Remote e-Working. [pdf] Employee Relations, 41 (1): 1633. DOI:10.1108/ER-09-2017-0229. Retrieved: https://pure.coventry.ac.uk/ws/portalfiles/portal/21366788/Binder1.pdf Access: 13.03.2021.

9. Labour Protection Law of the Republic of Latvia (2001). Retrieved: https://likumi.lv/ta/id/26020-darbaaizsardzibas-likums Access: 14.03.2021.

10. Livina, A., Rozentale, S. (2020). Challenge of Talent Attraction in Small and Medium Urban Areas: Case of Valmiera City, Latvia. In: Rehm M., Saldien J., Manca S. (eds) Project and Design Literacy as Cornerstones of Smart Education. Smart Innovation, Systems and Technologies, vol 158. Springer, Singapore. Retrieved: https://doi.org/10.1007/978-981-13-9652-6_15 Access: 14.03.2021.

11. Livina, A., Rozentale, S., Brigsa, S., Andersons, A., Kreituze, I. (2016). Personal competences for future labour market in Vidzeme region, Latvia. In 17th annual international scientific conference. Web of Sciences. Retrieved: http://llufb.Ilu.Iv/conference/economic_science_rural/2016/Latvia_ESRD_42_2016-107-113.pdf Access: 14.03.2021.

12. Overbey, J.A. (2013). Telecommuter intent to leave. Leadersh. Organ. Dev. J.2013, 34, 680-699.

13. Spagnoli, P., Molino, M., Molinaro, D., Giancaspro, M. L., Manuti, A., and Ghislieri, C. (2020). Workaholism and Technostress During the COVID-19 Emergency: The Crucial Role of the Leaders on Remote Working. Retrieved: https://www.frontiersin.org/articles/10.3389/fpsyg.2020.620310/full Access: 14.03.2021.

14. State Revenue Service of the Republic of Latvia (07.05.2020.). Retrieved: https://www.vid.gov.Iv/lv/videjistatistiskais-dikstaves-pabalsta-sanemejs-jauna-ridziniece-ar-salidzinosi-nelielu-algu-0 Access: 14.03.2021.

15. Vanadzins, I., Linde, A. A., Matisane, L., Paegle, L., Rozentale, S., Grintale, I., Arbidane, I., Litavniece, L., Lonska, J., Mietule, I. (2020). Assessment and proposals for the necessary changes in policies and / or regulations to promote employment and a safe working environment in the context of restrictions on the spread of COVID-19. Retrieved: http://stradavesels.Iv/Uploads/2021/01/05/31_zinojums_c.pdf Access: 14.03.2021. 